\title{
Telaah Kritis Buku Ajar Bahasa Arab Di Madrasah Ibtidaiyah
}

\author{
Pradi Khusufi Syamsu \\ IAIN Syekh Nurjati Cirebon \\ Email: pradikhusufi@gmail.com
}

\begin{abstract}
Abstrak
Artikel sederhana ini menyimpulkan bahwa metode yang tercermin pada buku ajar MI kelas I berjudul Buku Ajar Bahasa Arab MI Kelas I dalam pengajaran baca tulis bahasa Arab menggunakan metode sintetis dan mentode analisis secara terpisah dalam pengajaran baca tulis kosa kata Arab. Sedang dalam tataran silabus, buku ajar bahasa Arab untuk kelas I MI ini cenderung pada silabus situasional. Hal ini dapat dilihat dari pembelajarannya dari tematema tertentu yang tidak terlepas dari tempat, keadaan, dan waktu bahasa Arab itu digunakan dalam pembelajarannya. Buku ini layak untuk menemani para pelajar yang duduk di kelas I Madrasah Ibtidaiyah dalam belajar berbahasa Arab sebagai bahasa kedua. Hanya bagaimana seorang guru, sebagai man behind the gun, dalam mengajarkannya di hadapan para peserta didik.
\end{abstract}

Kata Kunci: Buku Ajar Bahasa Arab, Madrasah Ibtidaiyah, Silabus Situasional.

\begin{abstract}
This article concludes that the method is reflected in class I MI textbooks entitled Arabic Textbooks in Class I MI in Arabic reading and writing using synthetic methods and separate analysis methods in reading and writing Arabic vocabulary. While in the syllabus level, Arabic textbooks for class I MI tend to be in a situational syllabus. This can be seen from the learning of certain themes that are inseparable from the place, circumstances, and the time the Arabic language was used in the learning. This book is worthy to accompany students who sit in class I of the Islamic Elementary School in learning Arabic as a second language. Only how a teacher, as a man behind the gun, teaches the students.
\end{abstract}

Keywords: Arabic Language Textbook, Madrasa Ibtidaiya, Situational Syllabus.

\section{Pendahuluan}

Bahasa Arab di lembaga pendidikan Islam dapat dikatakan bahasa utama. Sebab, peradaban manapun yang bersentuhan dengan Islam pasti harus menerima bahasa Arab. ${ }^{1}$ Alhasil, pembelajaran bahasa Arab di Indonesia tidak saja dimulai pada tingkat madrasah melainkan ia juga

\footnotetext{
${ }^{1}$ Pradi Khusufi Syamsu, Scrutinizing the Role of Arabic in Shaping Literacy in Indonesia, dalam Jurnal El-Ibtikar, Vol. 6, No. 2. Hal. 101.
} 
sudah diajarkan pada tingkat pra madrasah atau sekolah di Indonesia, seperti di tingkat Raudhatul Atfal (RA) atau Taman Pendidikan AlQur'an (TPA). ${ }^{2}$ Dalam makalah yang sederhana ini penulis mencoba mengkaji dan mendiskusikan buku ajar bahasa Arab untuk kelas I Madrasah Ibtidaiyah.

Kajian kritis akan sebuah buku amat penting. Bukan saja akan menjadikan dunia buku semakin berkembang namun juga menajamkan daya kritis pembaca. Seorang Budayawan Emha Ainun Najib berkata, hendaklah daya kritis dalam membaca yang diutamakan, karena semutu-mutu isi sebuah buku manfaat yang akan muncul tidak berdasar pada mutu buku itu, melainkan bertolak dari kadar kecerdasan dan kritisisme pembacanya atau penggunanya. Bahkan segala kitab suci dan semua disertasi para doktor tidaklah bermanfaat sama sekali bagi seekor kera. ${ }^{3}$ Thus, mengkaji sebuah buku ajar bahasa Arab menjadi urgen.

\section{Keutamaan Bahasa Arab}

Para ilmuan dan cendekiawan sepakat bahwa bahasa Arab merupakan bahasa yang paling lama digunakan dan lebih awal munculnya, dan ia tergolong bahasa samiyah yang lebih maju, lebih lengkap dan lebih dekat dengan bahasa ibu dengan bahasa-bahasa yang satu asal dengannya yaitu Suryaniyah, Asyuriah, Habasyiyah dan Babiloniah. ${ }^{4}$

Jika bahasa Arab merupakan bahasa yang lebih maju dari bahasabahasa yang satu ibu dengannya maka dialek Quraisy merupakan dialek bahasa Arab yang paling maju, karenanya Al Qur'an turun dengan dialeknya. Abu Nashr al Farabi menegaskan bahwa: Dialek Quraisy merupakan dialek Arab yang paling bagus, bersih dan fasih lafazhnya; dan paling mudah diucapkan dengan lisan; paling enak didengar; paling nyata penjelasannya dalam jiwa. ${ }^{5}$ Ibnu Khaldun menjelaskan realitas tersebut dengan menyatakan: Oleh karena itu bahasa Quraisy

${ }^{2}$ Lihat M Hamid dan K Rohim, Cara Cepat Mengenal Bahasa Arab Untuk Anak-Anak TK/TPA. (Surabaya: CV. Pustaka Agung Harapan, 1999).

3 Emha Ainun Nadjib, Ali Syari'ati; dari Basyar ke Yaqut dalam Suwito NS, Transformasi Sosiologi; Kajian Epistimologis Ali Syari'ati tentang pemikiran Islam Modern. (Yogyakarta: Unggun Religi \& STAIN Purwokerto: STAIN Press, 2004). Hal. 11.

${ }^{4}$ Anwar al Jundi, Muqaddimat al 'Ulum wa al Manahij; Muhawalah libina'i Manhajin Islamiyyin Mutakamil, jilid: 4. (Kairo: Dar al Anshar). Hal. 5.

${ }^{5}$ Jalaluddin al Suyuthi, Al Mazhar, jilid: 1. (Kairo: Dar Ihya al Kutub al 'Arabiyah 'Isa al Babi al Halabi wa Syuraka'uh). Hal. 211. 
merupakan bahasa Arab yang paling fasih dan jelas yang jauh dari pengaruh bahasa-bahasa asing dari segala segi. ${ }^{6}$

Adapun sebab dari keunggulan dialek Quraisy ia dapat menembus luas keseluruh penjuru Arabia, karena ia merupakan pusat agama dan ekonomi. Pusat agama karena ia penjaga Ka'bah yang diziarahi oleh banyak kabilah-kabilah setiap musim haji. Sedang pusat perekonomian karena banyak kafilah-kafilah dari Quraisy melakukan perjalanan keseluruh penjuru jazirah Arabia sehingga terjadi terjadi komunikasi yang intens antara Quraisy dengan suku-suku lainnya. ${ }^{7}$ Al Qur'an juga menjelaskan tentang perjalanan perekonomian suku ini,

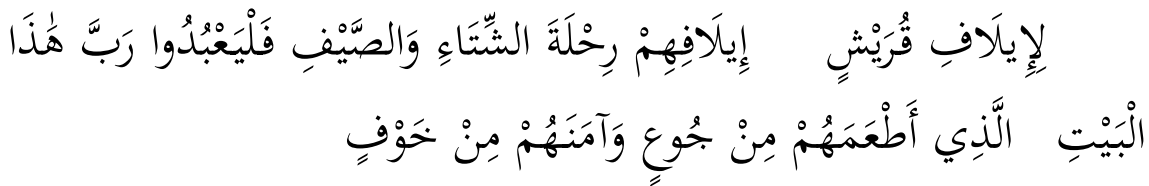

Karena kebiasaan orang-orang Quraisy, (yaitu) kebiasaan mereka bepergian pada musim dingin dan musim panas. Maka hendaklah mereka menyembah Tuhan Pemilik rumah ini (Ka'bah). Yang telah memberi makanan kepada mereka untuk menghilangkan lapar dan mengamankan mereka dari ketakutan. (QS. Quraisy: 1-4)

Bahasa Arab juga memiliki pengaruh pada bahasa-bahasa lainnya di dunia, termasuk Inggris, Rumania, Prancis, Persia, Portugal Italia, dan tidak terkecuali Indonesia. ${ }^{8}$

Bahasa melayu, sebagai cikal bakal bahasa Indonesia, merupakan bahasa yang paling banyak menerima pengaruh bahasa Arab terutama dalam peristilahan dan aksara. ${ }^{9}$ Cyril Skinner menyatakan bahwa bahasa Melayu adalah bahasa Nusantara yang secara leksikal banyak dipengaruhi oleh bahasa Arab. ${ }^{10}$ Bahkan Azyumardi Azra mencatat akan begitu banyaknya kosakata Arab dalam bahasa Melayu-Indonesia,

Kamus Al Hamidi, susunan Abdul Hamid Ahmad, mendaftar sekitar

2.000 kosakata Arab yang digunakan dalam bahasa Melayu-

6 'Ali 'Abdulwahid Wafi, Al Muqaddimah; Ta'liq wa Tahqiq, jilid: 4. (Kairo: Mathba'ah Lajnatilbayan al 'Arabi). Hal. 1389.

${ }^{7}$ Dihyatun Masqon, Al Ittijahat al Haditsah fi Ta'lim al Lughah al Arabiyah lighair al Nathiqina biha fi Indonesia; Dirasah Thliliyyah Washfiyyah. (New Delhi: Risalah Dukturah fi al Jami'ah al Milliyah al Islamiyyah, 2000). Hal. 3.

8 Karim Sayyid Ghanim, Al Lughah al 'Arabiyyah wa al Shahwah al Ilmiyyah al Haditsah. (Kairo: Maktabah Ibn Sina). Hal. 14-20.

${ }^{9}$ Azyumardi Azra, Renaisans Islam Asia Tenggara; Sejarah Wacana dan Kekuasaan. (Bandung: PT Remaja Rosdakarya, 2006). Hal.76.

${ }^{10}$ Lihat Cyril Skinner, The Influence of Arabic upon Modern Malay, dalam Intisari, Vol. II, No. Hal. 34-47. 
Indonesia. Sedangkan Guguskatan Arab Melayu, karya Muhammad Said, mencatat sejumlah 1.725 kosakata Arab dalam bahasa MelayuIndonesia. Dan, kamus Istilah Islamiyah, susunan Muhammad Sanusi ibn Haji Mahmood, mencatat sedikit dari 2.000 kosakata Arab. ${ }^{11}$

...James Howison mencatat hanya 150 kosakata Arab dalam lidah Melayu. Sedangkan Shellabear, yang menyusun kamus MelayuInggris, mendaftar sebanyak 385 kata. ... Winstedt dan Linggi dalam kitab loghat Melayu mencatat sebanyak 1.001 kosakata Arab yang dipergunakan dalam bahasa Melayu-Indonesia. ${ }^{12}$

... kamus Wilkinson berjudul An Abrigde Malay-English Dictionary mencatat 892 kata pinjaman Melayu dari bahasa Arab. Jumlah yang sama juga dikemukakan oleh Winstedt (A Practical Modern MalayEnglish Dictionary). Kemudian, kamus dewan susuan Tengku Iskandar mencatat 1.100 kosakata, dan kamus kebangsaan, karya Mohd. Kadir, mendaftar 1.125 kata. Sementara itu, Sudarno mencatat 2.302 kata bahasa Arab dalam bahasa Indonesia. ${ }^{13}$

Bertolak dengan pemikiran di atas, pembelajaran bahasa Arab tidak hanya bersifat ukhrawi, namun juga ada nilai-nilai dunia yang dapat digapai jika menguasai bahasa tersebut, baik yang sosial, budaya, ekonomi, politik dan teknologi. ${ }^{14}$ Maka, ketika salah satu dari keduanya tidak tercukupi akan terjadi ketimpangan alias pincang atau tidak seimbang. Padahal keseimbangan merupakan suatu panggilan fitrah manusia.

\section{Buku Ajar Bahasa Arab di MI}

Penulis memfokuskan kajian pada buku bahasa Arab untuk Madrasah Ibtidaiyah (MI) kelas I yang ditulis oleh Firman Hamdani, S.Ag., Ahmad Saehuddin, M.Ag., dan Halid al-Kaf, M.Ag. Buku yang dieditori H. Herdiansyah Ahmad, Lc. dan Ahmad Ta'yudin, Lc. Buku berjudul Buku Ajar Bahasa Arab MI Kelas I ini diterbitkan oleh penerbit Erlangga, sebuah penerbit yang berdiri pada 30 April 1952 dan konsen

${ }^{11}$ Azyumardi Azra, Renaisans Islam Asia Tenggara; Sejarah Wacana dan Kekuasaan. (Bandung: PT Remaja Rosdakarya, 2006). Hal.76.

${ }^{12}$ Azyumardi Azra, Renaisans Islam Asia Tenggara; Sejarah Wacana dan Kekuasaan. (Bandung: PT Remaja Rosdakarya, 2006). Hal.77.

${ }^{13}$ Azyumardi Azra, Renaisans Ism lam Asia Tenggara; Sejarah Wacana dan Kekuasaan. (Bandung: PT Remaja Rosdakarya, 2006). Hal.77.

${ }^{14}$ Mengenai "keduniaan" bahasa Arab khususnya lihat Ibrahim Anis, Al Lughah bayna al Qaumiyyah wa al 'Alamiyyah. (Kairo: Dar al Ma'arif).

El-Ibtikar Vol 7 No 1 Juni 2018, 93-108 
pada buku-buku pelajaran an sich. Namun kini Erlangga telah merambah ke buku anak, fiksi, non fiksi, dan juga majalah.

Penerbit Erlangga di tahun 2018 kembali meraih penghargaan prestisius Top Brand for Teens 2018, sebuah penghargaan keenam kali secara berturut-turut (2013-2018) untuk kategori "Buku Pendidikan". Penghargaan ini menggambarkan eksistensi buku-buku Erlangga di dunia pendidikan memiliki citra yang baik di mata masyarakat Indonesia.

Berikut ini klasifikasi umum Buku Ajar Bahasa Arab MI Kelas I,

\begin{tabular}{|l|l|l|}
\hline No & Klasifikasi & \multicolumn{1}{|c|}{$\begin{array}{c}\text { Buku Ajar B. Arab MI I } \\
\text { Kelas }\end{array}$} \\
\hline 1 & Penulis & $\begin{array}{l}\text { Firman Hamdani, S.Ag. } \\
\text { Ahmad Saehuddin, M.Ag. } \\
\text { Halid al Kaf, M.Ag. }\end{array}$ \\
\hline 2 & Editor & $\begin{array}{l}\text { H. Herdiansyah Ahmad, Lc. } \\
\text { Ahmad Ta'yudin, Lc. }\end{array}$ \\
\hline 3 & Reader & Dr. H. Rofi'i. \\
\hline 4 & Penerbit & Erlangga \\
\hline 5 & Cover & Soft Cover \\
\hline 6 & Jilid & Baik \\
\hline 7 & Kertas & Putih \\
\hline 8 & Jumlah halaman & 73 (tanpa penomeran) \\
\hline 9 & Panduan alokasi waktu & Ada \\
\hline 10 & Panduan pengajaran & Ada \\
\hline 11 & Warna & Full color \\
\hline 12 & Gambar & Ada \\
\hline 13 & Latihan semester & $\begin{array}{l}\text { Pilihan ganda } \\
\text { Mencocokan gambar } \\
\text { Melengkapi kata } \\
\text { Essay }\end{array}$ \\
\hline 14 & Kamus bergambar & Ada \\
\hline 15 & Daftar pustaka & 10 buku \\
\hline & & \\
\hline
\end{tabular}


Buku ajar untuk Madrasah Intida'iyyah kelas I yang diterbitkan oleh penerbit Erlangga ini setebal 73 halaman mulai dari kata pengantar hingga daftar pustaka. Membuka buku ini sebagaimana layaknya membuka buku-buku berbahasa Arab pada lazimnya yakni, dimulai dari sebelah kanan bertolak belakang dengan buku-buku yang beraksara latin yang dimulai dari sebelah kiri.

Buku ini untuk dua semester pada kelas I MI dengan mengajarkan Ta'aruf, al Adawat al Madrasiyyah, al Asyya' fil fasli dan tidak ketinggalan Muraja'ah untuk ketiga tema di atas. Untuk tema Ta'aruf sangat mendominasi dalam semester pertama. Hal itu terlihat dengan memecah Ta'aruf menjadi tiga bab yaitu Ta'aruf I, Ta'aruf II dan Ta'aruf III.

Pada Ta'aruf I siswa/i MI difokuskan agar dapat membaca, bercakap dan menulis dalam berbahasa Arab dengan menggunakan kata-kata:

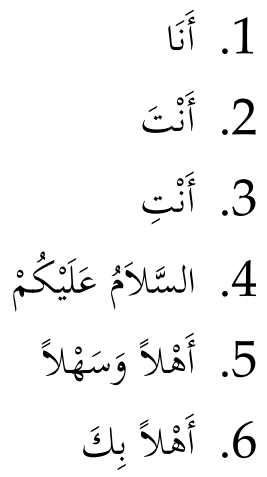

Sedang pada Ta'aruf II tetap menekanakan ketiga kompetensi di atas, yakni membaca, bercakap dan menulis dengan tambahan kosakata هذدِ هذِ dan Adapun untuk Ta'aruf III tidak jauh berbeda dengan bab-bab

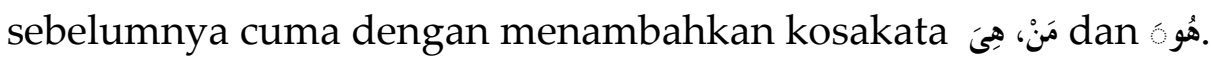

Untuk lebih jelas, sajian materi semester I pada buku ini adalah sebagai berikut:

\begin{tabular}{|c|c|c|c|c|}
\hline No & Materi & Ta'aruf I & Ta'aruf II & Ta'aruf III \\
\hline 1 & $\begin{array}{l}\text { Pengenal } \\
\text { an } \\
\text { mufrada } \\
\text { t baru }\end{array}$ & 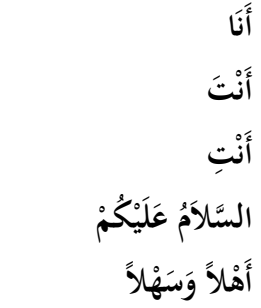 & هذَ هَدِ & صَنْ هِيَّْ \\
\hline
\end{tabular}

El-Ibtikar Vol 7 No 1 Juni 2018, 93-108 


\begin{tabular}{|c|c|c|c|c|}
\hline & & أَهْلاً بِكَ & & \\
\hline 2 & $\begin{array}{l}\text { Percakap } \\
\text { an }\end{array}$ & 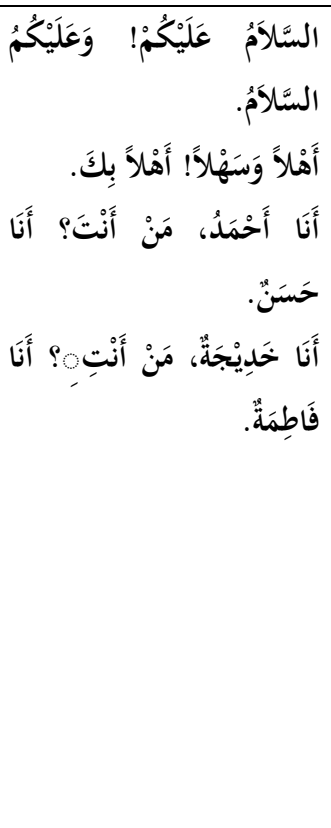 & 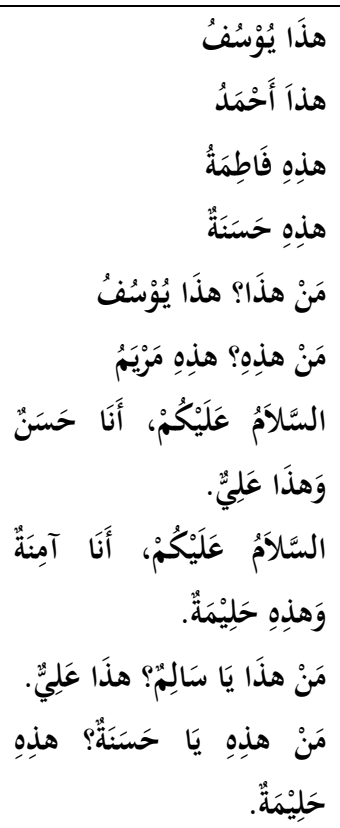 & 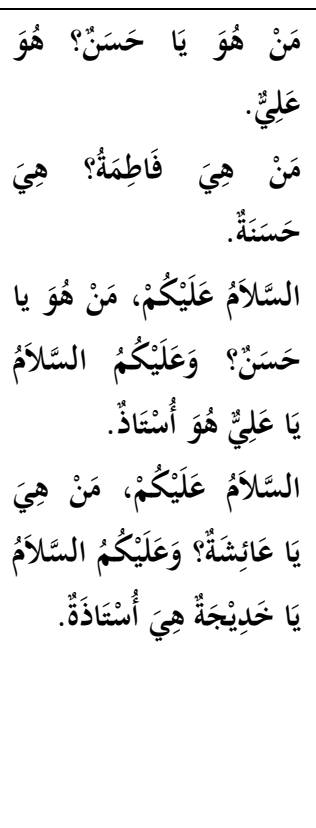 \\
\hline 3 & $\begin{array}{l}\text { Belajar } \\
\text { melengk } \\
\text { api }\end{array}$ & 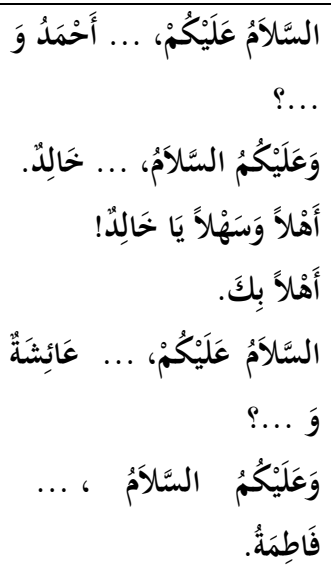 & 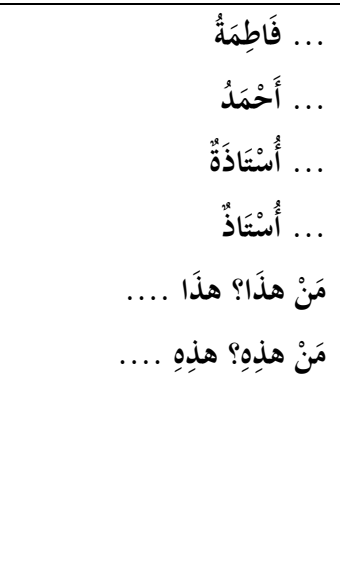 & 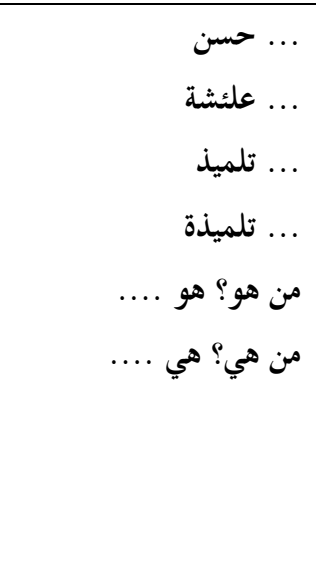 \\
\hline 4 & $\begin{array}{l}\text { Belajar } \\
\text { menulis }\end{array}$ & نا نا & هذه & و \\
\hline
\end{tabular}




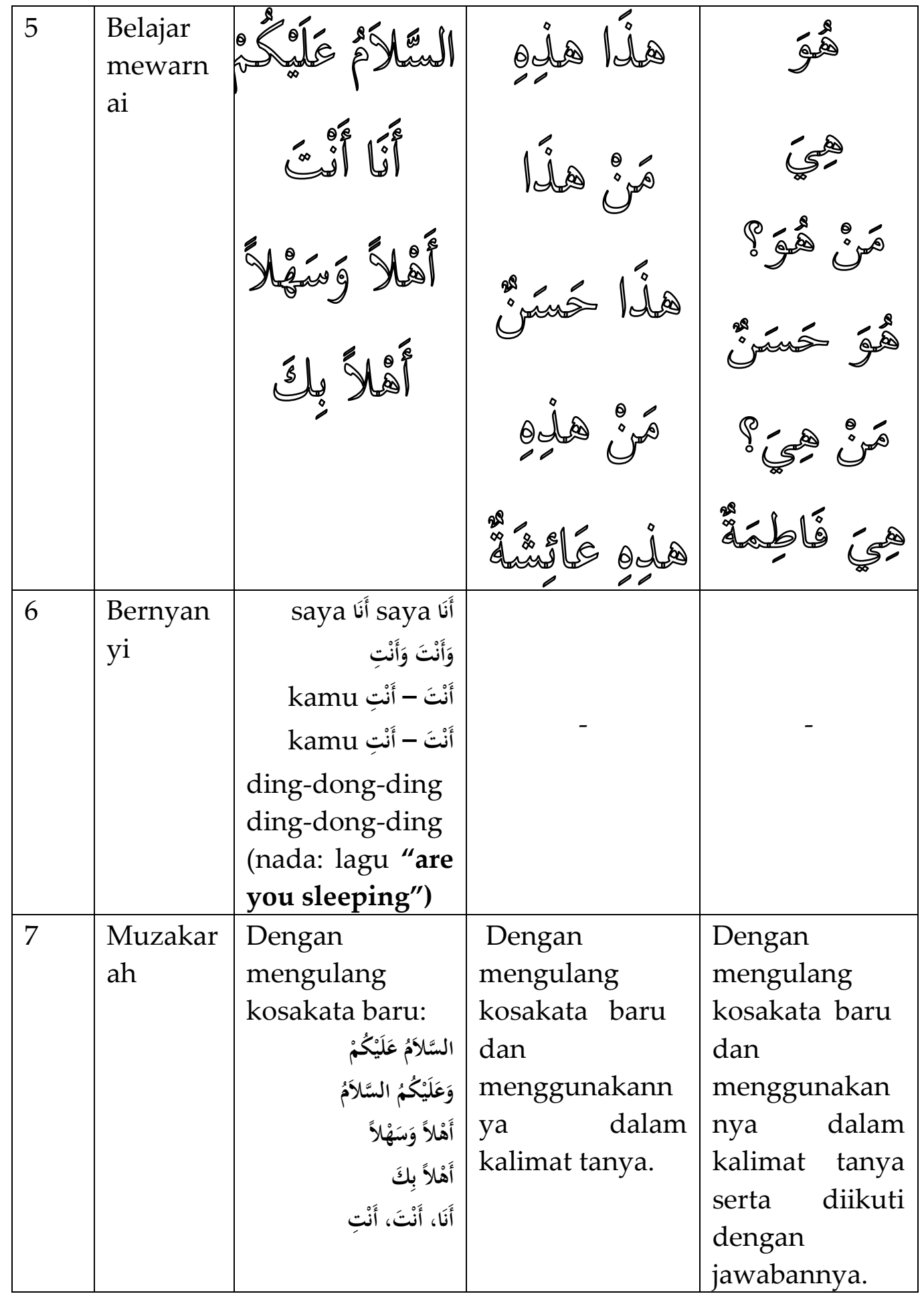

Adapun untuk penyajian materi semester II Madrasah Ibtidaiyah kelas I dalam buku ini adalah sebagai berikut:

\begin{tabular}{|l|l|l|l|l|}
\hline No & Materi & Al Adawat al & Al Asyya fi & Muraja'ah \\
\hline
\end{tabular}




\begin{tabular}{|c|c|c|c|c|}
\hline & & Madrasiyyah & al Fasli & \\
\hline 1 & $\begin{array}{l}\text { Penganalan } \\
\text { mufradat } \\
\text { baru }\end{array}$ & 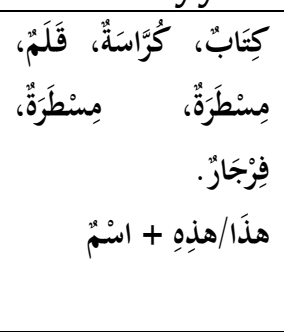 & 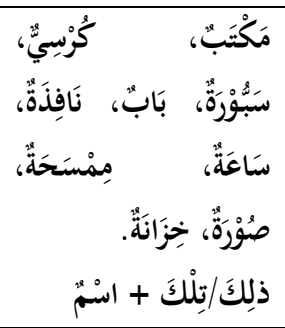 & $\begin{array}{l}\text { Dalam Muraja'ah } \\
\text { berisikan perintah } \\
\text { agar para siswa } \\
\text { mencoba } \\
\text { mengenalkan } \\
\text { dirinva masing- }\end{array}$ \\
\hline 2 & Percakapan & 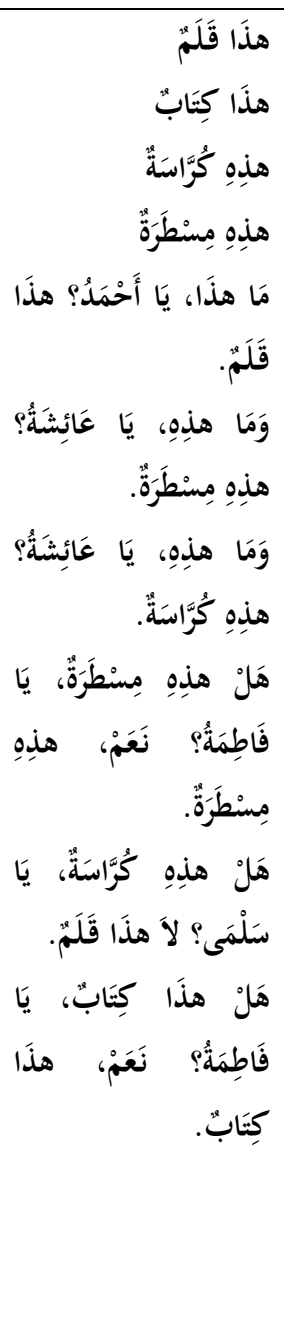 & 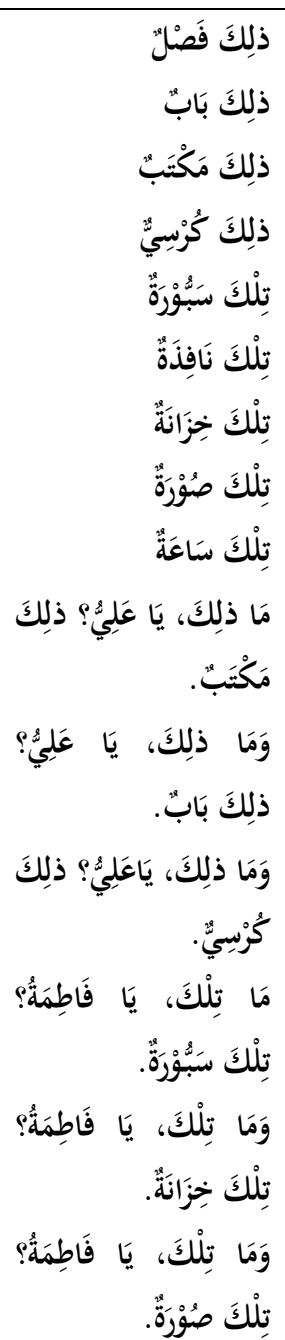 & $\begin{array}{l}\text { masing secara } \\
\text { berpasangan, } \\
\text { disamping itu } \\
\text { juga } \\
\text { menghafalkan } \\
\text { kosakata-kosakata } \\
\text { Arab yang } \\
\text { tercamtum dalam } \\
\text { buku ini. }\end{array}$ \\
\hline 3 & $\begin{array}{l}\text { Belajar } \\
\text { melengkapi }\end{array}$ & 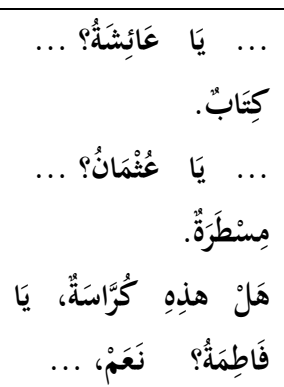 & 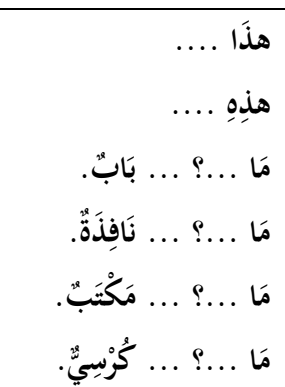 & \\
\hline
\end{tabular}




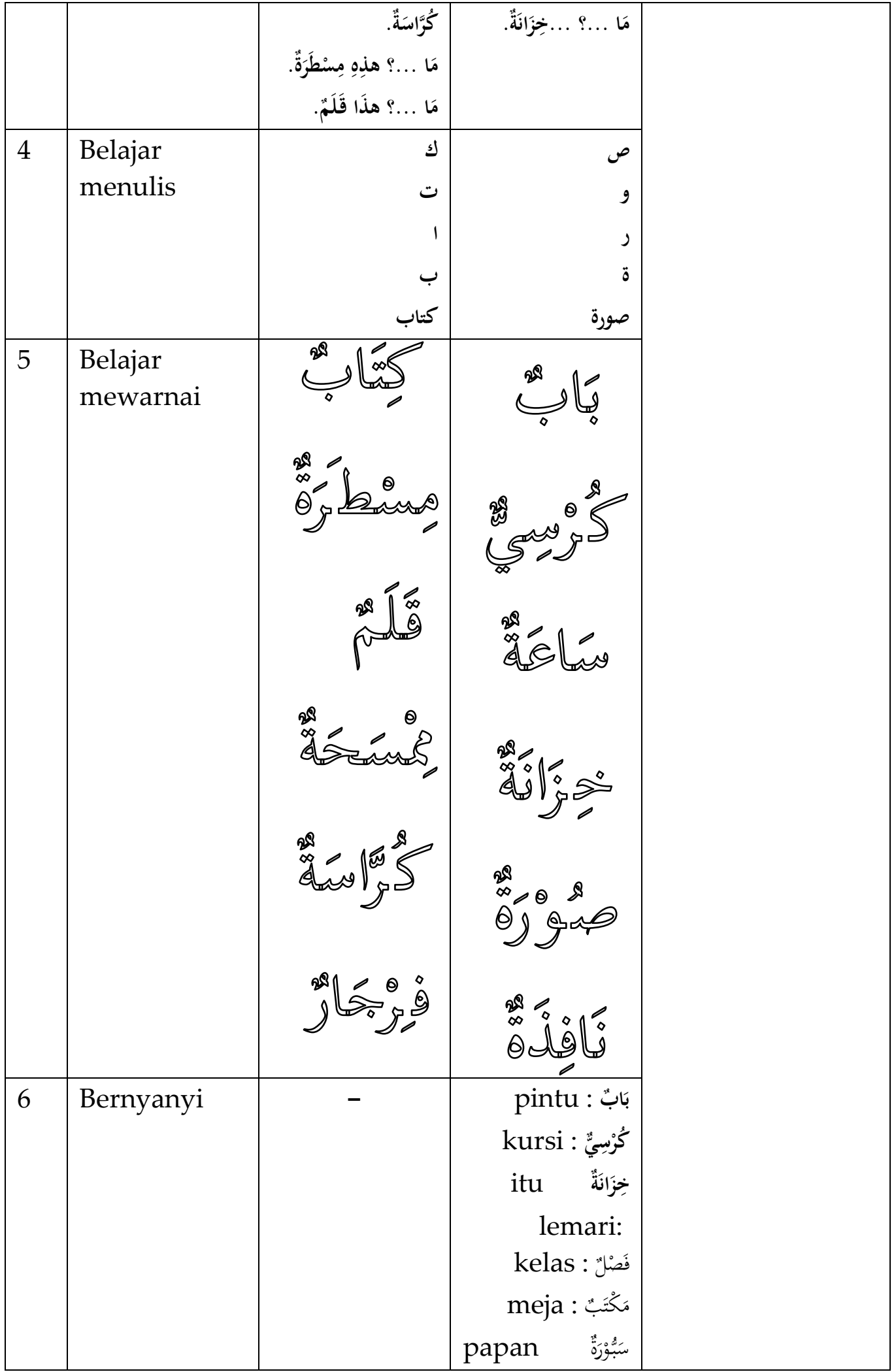




\begin{tabular}{|c|c|c|c|}
\hline & & & 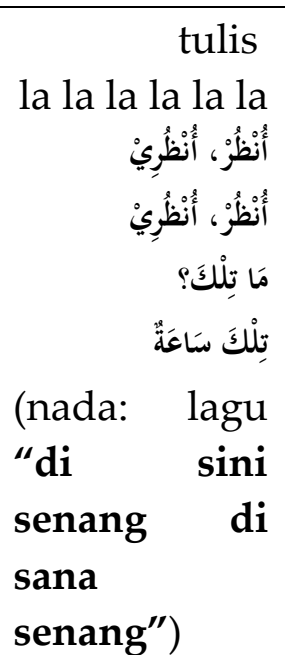 \\
\hline 7 & Muzakarah & $\begin{array}{l}\text { Mengulang- } \\
\text { ngulang } \\
\text { kosakata- } \\
\text { kosakata } \\
\text { baru. }\end{array}$ & $\begin{array}{l}\text { Mengulang- } \\
\text { ngulang } \\
\text { kosakata- } \\
\text { kosakata } \\
\text { baru. }\end{array}$ \\
\hline
\end{tabular}

Buku yang kaya akan warna ini juga dilengkapi dengan kamus bergambar, disamping menyebutkan buku-buku rujukan sebagai rujukan dalam penulisan buku ini sebanyak 10 buku. Lima buku dalam berbahasa Arab dan lima yang tersisa berbahasa Indonesia.

\section{Analisis Kritis}

"Menguasai kaidah-kaidah an sich dan menghafalkan kosa kata lepas adalah sia-sia, dan bahwa upaya menundukkan kaidah bahasa kepada prinsipprinsip logika adalah bertentangan dengan tabiat bahasa yang spontan.......cara belajar melalui gerakan dan aktivitas yang langsung menyertai ungkapan bahasa, atau gambar-gambar yang konkrit, tanpa terlalu dibebani dengan penguasaan kaidah-kaidah."15 Nampaknya, statement di atas sejalan dengan apa yang telah disajikan dalam buku ini.

Buku ini sama sekali tidak membebani para pelajarnya untuk memahami kaidah-kaidah bahasa Arab, meskipun sangat jelas bahwa di kelas I madrasah peserta didik diajarkan tentang jumlah ismiyah dengan menggunakan kata tunjuk dan kata ganti untuk mu'annas dan mudzakkar, serta tanpa menjelaskan kaidah-kaidah nahwunya sama sekali. Karena

${ }^{15}$ Statement di atas merupakan pendapat John Amos Comenius, seorang pendidik Cheko yang hidup pada abad ke 17. Ahmad Fuad Effendy, Metodologi Pengajaran Bahasa Arab. (Malang: Misykat, 2005). Hal. 18. 
kalau saja demikian, tentu saja ada penjelasan tentang jumlah mufidah atau kalam, pembagian kalimah, Ism, fi'l, harf'16 dan seterusnya.

Ada beberapa teknik pengajaran baca tulis bahasa Arab antara lain:

a. Metode alpabetik, yaitu dimulai dengan mengenalkan nama-nama huruf dan ortoggrafi dengan tanda syakal di atas dan di bawah huruf. Seperti:

b. Metode bunyi, yaitu pembelajaran tidak dimulai dengan huruf melainkan dengan bunyi. Ada dua cara yang lazim digunakan dalam metode ini, pertama, cara sintetis, analitis dan gabungan keduanya analisis-sintetis. ${ }^{17}$

a) Metode sintetis dengan mengenalkan bunyi huruf-huruf, kemudian dirangkai menjadi kata. Misalnya, / أَ. أنْنَ.

b) Metode Analisis dimulai dengan kata kemudian dikupas

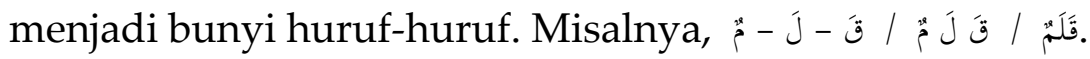

c) Metode analisis-sintetis, yaitu penggabungan dua metode, seperti:

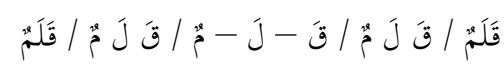

atau sebaliknya:

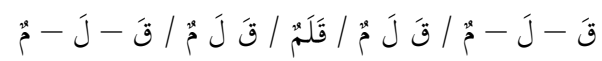

Merujuk pada metode-metode di atas, maka buku ajar MI kelas I dalam pengajaran baca tulis bahasa Arab menggunakan metode sintetis dan mentode analisis secara terpisah dalam pengajaran baca tulis kosa kata Arab.

Adapun sebelum mendiskusikan aspek kemampuan berbicara atau berkomunikasi yang dijabarkan dalam buku ini, maka ada baiknya jika menukil pendapat Savignon, Canale dan Swain mengenai kompetensi dalam berkomunikasi. Savignon menegaskan bahwa kemampuan dalam berkomunikasi didukung oleh kemampuan gramatika (grammatical competence), kemampuan sosiolinguistik (sociolinguistic competence), kemampuan wacana (discourse competence) dan kemampuan strategi (strategic competence). ${ }^{18}$

${ }^{16}$ Lihat 'Ali Al Jarim dan Mushthofa Amin, Al Nahw al Wadhih; fi al Qawa'id al Lughah al 'Arabiyyah, jilid I. (Surabaya: Maktabah Salim Nabhan). Hal. 82-83.

${ }^{17}$ Ahmad Fuad Effendy, Metodologi Pengajaran Bahasa Arab. (Malang: Misykat, 2005).

${ }^{18}$ William H. Walcott, Knowledge, Competence and Communication; Chomsky, Freire, Searle, and Communicative Language Teaching. (Montreal: Black Rose Books, 2006). Hal. 1. 
Sedang pendapat Canale dan Swain, dalam hal kompetensi berkomunikasi (communicative competence), setidak-tidaknya harus memiliki tiga kemampuan, antara lain: kemampuan gramatika, kemampuan sosiolinguistik dan kemampuan strategis. Pertama, berkaitan dengan ilmu leksikal dan morfologi, syntaks, grammar dalam kalimat, semantik, dan fonologi. Kedua, berkenaan dengan aturan-aturan sosialbudaya yang digunakan dan aturan-aturan wacana dimana keduanya sangat krusial dalam memahami ungkapan dalam arti sosial, terutama sekali ketika rendahnya tingkat kejelasan antara makna ungkapan literal dengan maksud pembicara. Ketiga, kemampuan strategis terdiri dari verbal dan non-verbal dimana dapat digunakan untuk mengganti atau mengimbangi kemacetan komunikasi yang diakibatkan oleh penggunaan yang tidak menentu dan kemampuan yang tidak memadai. Kemampuan strategis ada dua macam: pertama, sesuai dengan kemampuan gramatika; dan kedua, lebih berkaitan pada kemampuan sosiolinguistik. ${ }^{19}$

Lebih lanjut, Noam Chomsky membagi kemampuan berbahasa menjadi dua, yakni kompetensi dan performansi. Kompetensi merupakan kemampuan yang ideal yang dimiliki oleh seorang penutur, yang terdiri dari pengetahuan tentang sistem kalimat (sintaks), sistem kata (morfologi), sistem bunyi (fonologi) dan sistem makna (semantik). Adapun performansi merupakan ujaran-ujaran yang bisa didengar atau dibaca, yang merupakan ucapan seseorang apa adanya tanpa dibuatbuat. Oleh karenanya, menurut Chomksy, tatabahasa mestinya memperhatikan kompetensi bukan performansi. ${ }^{20}$

Membaca buku ajar bahasa Arab untuk MI kelas I dengan "kacamata" di atas tentu tidak toleran. Karena buku ajar yang dikaji adalah untuk anak-anak yang masih berumur 6 tahunan. Adalah benar dan tidak dapat dipungkiri bahwa bahasa Arab memiliki aturan dan mantik tersendiri. Akan tetapi, seorang anak kecil tidak mampu mengetahui akan aturan dan mantik bahasa tersebut. Yang utama dalam pembelajaran anak-anak adalah penggunaan bahasa, baru kemudian mengenal aturannya dan dilanjutkan dengan belajar mantiknya. Jika

${ }^{19}$ William H. Walcott, Knowledge, Competence and Communication; Chomsky, Freire, Searle, and Communicative Language Teaching. (Montreal: Black Rose Books, 2006). Hal. 1-2.

${ }^{20}$ Ahmad Fuad Effendy, Metodologi Pengajaran Bahasa Arab. (Malang: Misykat, 2005). Hal. 15. 
tidak demikian, maka akan membebani anak-anak dan kadang-kadang dapat membuat mereka membenci pengajar dan pengguna bahasa tersebut. ${ }^{21}$

Sebelum mengurai kecenderungan buku ini terhadap silabus bahasa tidak ada salahnya menyebutkan jenis silabus terlebih dahulu. Setidaknya, ada empat silabus bahasa yaitu, silabus gramatika, silabus situasional, silabus notional dan silabus multidimensional. Silabus gramatika menekankan bagaimana seorang penutur mengungkapkan maksud yang dituju, maka yang diperhatikan adalah harakat atau struktur gramatika. Tidak jauh berbeda dengan silabus situasional dalam hal penggunaan struktur bahasa namun tidak murni dengan apa yang dipelajari dalam silabus sebelumnya. Sedang dalam silabus nosional, bahasa lebih pada perasaan atau rasa. Dan yang menonjol dalam silabus multidimensional adalah tsaqafah atau budaya. ${ }^{22}$

Bertolak dari pemikiran di atas, maka buku ajar bahasa Arab untuk kelas I MI masih cenderung pada silabus situasional, menimbang bahwa pembelajaran bahasa Arab berangkat dari tema-tema tertentu yang tidak terlepas dari tempat, keadaan dan waktu bahasa Arab itu digunakan dalam pembelajarannya.

Adapun nuansa figh dalam buku ajar ini masih kental namun wajar. Setidaknya, itu dilihat dari gambar-gambar yang termuat dalam buku ini. Yang demikian itu disebabkan konteks buku ini diajarkan di madrasah-madrasah di samping bahasa Arab sudah mengalami Islamisasi sejak turunnya al-Qur'an ke muka bumi di mana bahasa Arab dengan dialek Quraisylah ${ }^{23}$ yang dipilih oleh Allah ta' ala sebagai kalamNya. ${ }^{24}$

${ }^{21}$ Rusydi Ahmad Thu'aimah, Ta'lim al Arabiyah lighair al Nathiqin biha; Manahijuhu wa asalibuhu. (Jami'ah al Manshurah, 1410/1989). Hal. 76.

${ }^{22}$ Rusydi Ahmad Thu'aimah, Ta'lim al Arabiyah lighair al Nathiqin biha; Manahijuhu wa asalibuhu. (Jami'ah al Manshurah, 1410/1989). Hal. 99-106.

${ }^{23}$ Abu Daud telah meriwayatkan dari Ka'ab al Anshari, bahwasanya Umar ra menulis surat kepada Ibn Mas'ud “Al Qur'an telah diturunkan dalam dialek Quraisy, maka ajarkanlah

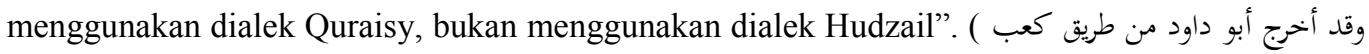
(الأنصاري أن عمر كتب إلى بن مسعود أن القرآن نزل بلسان قريش فأقريء الناس بلغة قريش لا بلغة هذيل . Ibn Hajar al 'Asqalani, Fath al Bari, ix: 9.

${ }^{24}$ Adi Setia, Hakikat Bahasa Menurut Chomsky dan al Attas, dalam Islamia Thn. I No. 2. Hal. 92. 


\section{Kesimpulan}

Jelas, buku ajar merupakan faktor eksternal dalam pembelajaran bahasa Arab. Oleh karenanya, buku memiliki peranan penting dalam proses menjadikan peserta didik dapat mencapai target yang semestinya, yaitu mampu dalam bertutur dalam bahasa yang diajarkan. Bukankah "the brains of races of people are equipotent in respect of the languages of the world". ${ }^{25}$ Maka, faktor kemampuan alamiah sebagai faktor internal manusia harus mendapat dukungan faktor eksternal baik buku, guru, maupun lingkungan.

Menurut hemat penulis, buku Belajar Bahasa Arab untuk Madrasah Ibtidaiyah sudah layak untuk menemani para pelajar yang duduk di kelas I Madrasah Ibtidaiyah dalam belajar berbahasa Arab sebagai bahasa kedua. Hanya bagaimana seorang guru, sebagai man behind the gun, dalam mengajarkannya di hadapan para peserta didik. Sebagaimana telah disinggung di muka bahwa semutu-mutu isi sebuah buku manfaat yang akan muncul tidak berdasar pada mutu buku itu, melainkan bertolak dari kadar kecerdasan dan kritisisme pembacanya atau penggunanya, karena segala kitab suci dan semua disertasi para doktor tidaklah bermanfaat sama sekali bagi seekor kera.

Di era teknologi yang maju pesat, hendaknya pembelajaran bahasa pun mengikuti perkembangan yang terjadi. Ada baiknya jika buku ajar dilengkapi dengan CD atau DVD agar dapat lebih menarik perhatian para peserta didik dalam proses pembelajaran.

\section{DAFTAR PUSTAKA}

$\mathrm{Al}$ ‘Asqalani, Ibn Hajar. Fath al Bari, ix: 9.

Al Jundi, Anwar. Muqaddimat al 'Ulum wa al Manahij; Muhawalah libina'i Manhajin Islamiyyin Mutakamil. (Kairo: Dar al Anshar).

Al Suyuthi, Jalaluddin. Al Mazhar. (Kairo: Dar Ihya al Kutub al 'Arabiyah 'Isa al Babi al Halabi wa Syuraka'uh).

Amin, Ali Al Jarim dan Mushthofa. Al Nahw al Wadhih; fi al Qawa'id al Lughah al 'Arabiyyah. (Surabaya: Maktabah Salim Nabhan).

Anis, Ibrahim. Al Lughah bayna al Qaumiyyah wa al 'Alamiyyah. (Kairo: Dar al Ma'arif).

${ }^{25}$ Eccles, Human Psyche. (Berlin \& New York: Springger-Verlag, 1979). Hal. 195.

El-Ibtikar Vol 7 No 1 Juni 2018, 93-108 
Azra, Azyumardi. 2006. Renaisans Islam Asia Tenggara; Sejarah Wacana dan Kekuasaan. (Bandung: PT Remaja Rosdakarya).

Eccles. 1979. Human Psyche. (Berlin \& New York: Springger-Verlag).

Effendy, Ahmad Fuad. 2005. Metodologi Pengajaran Bahasa Arab. (Malang: Misykat).

Ghanim, Karim Sayyid. Al Lughah al 'Arabiyyah wa al Shahwah al Ilmiyyah al Haditsah. (Kairo: Maktabah Ibn Sina).

Masqon, Dihyatun. 2000. Al Ittijahat al Haditsah fi Ta'lim al Lughah al Arabiyah lighair al Nathiqina biha fi Indonesia; Dirasah Thliliyyah Washfiyyah. (New Delhi: Risalah Dukturah fi al Jami'ah al Milliyah al Islamiyyah).

Rohim, M Hamid dan K. 1999. Cara Cepat Mengenal Bahasa Arab Untuk Anak-Anak TK/TPA. (Surabaya: CV. Pustaka Agung Harapan).

Thu'aimah, Rusydi Ahmad. 1410/1989. Ta'lim al Arabiyah lighair al Nathiqin biha; Manahijuhu wa Asalibuhu. (Jami'ah al Manshurah).

Wafi, Ali Abdulwahid. Al Muqaddimah; Ta'liq wa Tahqiq. (Kairo: Mathba'ah Lajnatilbayan al 'Arabi).

Walcott, William H. 2006. Knowledge, Competence and Communication; Chomsky, Freire, Searle, and Communicative Language Teaching. (Montreal: Black Rose Books).

Intisari, Vol. II.

Islamia Thn. I No. 2. 